\title{
Assessment of dynamic forces in new construction design for beamless sucker-rod pumping units
}

\section{Ocena sił dynamicznych w nowym rozwiązaniu konstrukcyjnym zespołów pomp żerdziowych bez żurawia}

\author{
Beyali Ahmedov, Anar Hajiyev \\ Department of Machine Design of Azerbaijan Technical University
}

\begin{abstract}
The article addresses the issue of determining the dynamic forces acting on the rod suspension point during the operation of the well in a new construction design for a beamless pumping unit, depending on the angle of rotation of the crank and the dimensionless kinematic parameters, which characterize the relationship of the crank length to the rod length and relative eccentricity. It was found that the value of the dynamic loads in the rod column depends on the type of the rocking machine and on the direction the crank rotates. In addition, one of the adverse factors for the operation of the pumping unit is that the force at the rod suspension point is constantly directed downwards, and that it varies during the course of the polished rod down- and upstrokes, which leads to uneven loading of the electric motor. This mode of operation for the engine and gearbox is abnormal and comes with a sharp decrease in their efficiency. To equalize the load on the gearbox and engine during one cycle of work, and to reduce the engine power needed to carry out the balancing process, a combination of movable and rotary counterweights is applied in the proposed design to balance the pumping unit. To this end, an investigation was made of the method of balancing a new structural design of the pumping unit and proposed analytical expressions for determining the weight of the movable and rotary counterweights when moving the rod suspension point up and down using combined balancing. The article discusses options for determining the dynamic forces in both a non-balanced (without using any counterweights) and a combined balanced (by using both moving and rotary counterweights) oil pumping unit.
\end{abstract}

Key words: pumping unit, balancer, rotor, crank, counterweight, static forces, dynamic forces, rod suspension point.

STRESZCZENIE: Artykuł omawia zagadnienie określenia sił dynamicznych działających w punkcie podparcia żerdzi w czasie eksploatacji odwiertu w nowym rozwiązaniu konstrukcyjnym zespołów pompowych bez żurawia, zależnych od kąta obrotu korby i bezwymiarowych parametrów kinematycznych, charakteryzujących zależność między długością korby a długością żerdzi i względną mimośrodowością. Stwierdzono, że wartość obciążeń dynamicznych w kolumnie żerdzi zależy od rodzaju wahacza i od kierunku obrotów korby. Ponadto jednym z niekorzystnych czynników eksploatacji zespołów pompowych jest fakt, że siła w punkcie zawieszenia żerdzi jest stale skierowana w dół, a jej wartość zmienia się w trakcie ruchów wypolerowanej żerdzi w dół i w górę, co prowadzi do nierównego obciążenia silnika elektrycznego. Ten tryb pracy silnika i przekładni jest nieprawidłowy i powoduje ostry spadek ich sprawności. Aby wyrównać obciążenie przekładni i silnika w czasie jednego cyklu pracy oraz zmniejszyć moc silnika wykonującego ten proces równoważenia, w proponowanej konstrukcji równoważenia zespołu pompowego zastosowano kombinację równoważenia składającą się z przeciwciężarów przesuwnych i obrotowych. W tym celu zbadano metodę równoważenia nowej konstrukcji strukturalnej zespołu pompowego i zaproponowano wyrażenia analityczne do określenia wagi przeciwciężarów przesuwnych i obrotowych, kiedy punkt zawieszenia żerdzi przesuwa się w górę i w dół, używając równoważenia łączonego. Artykuł omawia warianty określenia sił dynamicznych w zespole pompowym ropy niezrównoważonym (bez zastosowania przeciwwag) i z kombinacją sposobów zrównoważenia (przez zastosowanie przeciwwag przesuwnych i obrotowych).

Słowa kluczowe: zespół pompowy, wyrównywacz, wirnik, korba; przeciwwaga, siły statyczne, siły dynamiczne, punkt zawieszenia żerdzi.

\section{Introduction}

One of the main parameters of a pumping unit is the load at its rod suspension point. This parameter largely determines the correct selection of the pumping unit, depending on its operating conditions. It is necessary to calculate the values of the factors that determine the magnitude of the efforts on the horse head and the method of their calculation. The main

Corresponding author: B. Ahmedov, e-mail:ahmedov.beyali@mail.ru

Article contributed to the Editor: 08.11.2019. Approved for publication: 29.04.2020 
feature is that the loads acting on the rod suspension point vary in size based on the direction of the horse head's stroke. In addition to static loads caused by the weight of the rod, the fluid column inside the tubing string, and friction forces - the forces of friction from the plunger working on the cylinder and rods on the tubing string, dynamic loads - the inertial forces of the rod string movement, the liquid column, and the rod string vibration - also act on the horse head. The magnitude of these forces is determined by the ratio of the elements of the pumping unit and the number of double strokes. The friction force is $2-5 \%$ of the magnitude of the static forces.

Pumping units are an integral technology used in the oil industry. Currently, various pumping installations are used to operate oil wells in a mechanized way. Different kinds of pumping units are used in the exploitation of oil wells in a mechanized way.

Of the existing mechanized methods of oil production, the most common is the sucker-rod pumping machine with balanced individual drives - the machine of mechanical action - which is called the rocking machine (Aliverdizade, 1951; Chicherov et al., 1987). For many years, research has described the theory of work, analysis, and synthesis of the kinematics of ordinary and unusual balancing of individual drives, the law of change of effort at the rods' suspension point, the power calculation of pumping units, and the design features of typical types of balancing pumping units (Adonin, 1973; Ivanovsky et al., 2002; Mishchenko, 2003). The main disadvantages of the pumping units are their metal-intensive construction, low efficiency, poor balance, and the need for a massive foundation, among other things.

The high energy consumption during operation and the consumption of materials in the construction of pumping units has led to the development of new design solutions for this technology. One of the main trends in this area is the development of beamless pumping units. The advantage of these pumping units is their smaller size, less metal material needs, less energy consumption, and better dynamic characteristics (Abdullaev et al., 2016).

For the kinematic study of a new construction design for beamless pumping units, some articles (Ahmedov et al., 2015, 2018; Abdullaev et al., 2019) have proposed new analytical expressions to determine the actual movement, speed, and acceleration of the rod suspension point, and have presented analytical studies and numerical calculations for a new construction design for beamless pumping units.

One of the main tasks in the operation of pumping units is to reduce the dynamic forces at the rod suspension point by balancing it correctly. For this purpose, the study carried out on the method of balance has proposed analytical expressions to determine the torque on the output shaft of the gearbox when the rod suspension point moves up and down by using combined balancing for the new construction design of the pumping unit (Ahmedov et al., 2018). To equalize the load on the drive engine of the pumping unit, some authors (Agamalov et al., 2010) have proposed equipping the pumping unit with a wellhead-balancing load and a method for calculating the weight of the proposed wellhead-balancing load for the static and dynamic operation of the well during the relaxation of the pumped product. The aim of this paper is to determine the dynamic forces acting on the rod suspension point in a new construction design for a beamless rocking machine, according to the angle of rotation of the crank and dimensionless kinematic parameters, characterizing the ratio of the crank length to the rod length and relative eccentricity, and to obtain an analytical expression for estimating the dynamic coefficient.

To achieve this goal it is necessary to solve the following tasks:

- equalize the load on the gearbox and the engine during one cycle of operation, as well as to reduce the engine power needed to carry out the process of balancing a beamless rocker machine, that is, to determine the weight of the movable and rotor loads when the rod suspension point of the pumping unit move up and down using the combined balancing;

- estimate the acceleration of a rod suspension point of the pumping unit that moves move up and down in the new construction of a beamless rocking machine according to the angle of rotation of the crank and dimensionless kinematic parameters, which characterize the ratio of the crank length to the working part of the cable length and relative eccentricity;

- determine static and dynamic forces in the new construction of a beamless rocking machine in the absence of equilibrium;

- determine the critical frequency of the double strokes of the rod suspension point and the rocking machine dynamism factor;

- determine dynamic forces at the combined balancing of the pumping unit.

The total magnitude of the forces is calculated by the formula (let us ignore the forces of friction and vibration) (Aliverdizade, 1951; Chicherov et al., 1987; Ivanovsky et al., 2002; Mishchenko 2003):

$$
G_{\text {max }}=G_{\text {rod }}+G_{f l}+G_{\text {in }}=G_{r o d}+G_{f l}+G_{r o d}^{i n}+G_{f l}^{i n}
$$

where:

$G_{r o d}$ - is the force of gravity of the rod column,

$G_{f l}$ - is the weight of fluid above the plunger,

$G_{i n}-$ is the sum of the inertial force of the rod column and the fluid above the plunger,

$G_{r o d}^{i n}-$ is the inertial force of the rod column, and

$G_{f l}^{i n}-$ is the inertial force of fluid above the plunger. 
The static and dynamic modes of operation of the pumping unit must be determined based on some technological characteristics. For static operation modes of these units, the dynamic components in the total load acting on the rod column are minor and do not have a significant effect on the operation of the entire system. If the dynamic components are significant in size, they lead to significant differences in the operation of the pumping unit. The operating modes of the unit at which dynamic components are essential are called dynamic.

Consider the change in the dynamic load acting on the polished rod of the pumping unit during the operation of the well by the sucker-rod pump unit. The magnitude of the dynamic loads in the rods' column depends on the type of pumping unit and on the crank's direction of rotation.

One of the adverse factors for the operation of the pumping unit is that the force at the rod suspension point is constantly directed downwards, and its value during the course of the polished rod down- and upstrokes differs by $30-50 \%$, which leads to uneven loading of the electric motor (Adonin, 1973). In order to compensate for the difference in loads when the rod column moves up or down, the rocking machine must be balanced. The essence of balancing pumping units is to ensure uniform loading of the gearbox and engine during the upstroke and downstroke. This need is due to the fact that during the upstroke, the gearbox and the engine are loaded with a positive moment for lifting the rod columns and the liquid column in the tubing. While the rod suspension point moves down, the rod column pulls the cable downwards, so the gearbox and engine are loaded with a negative moment. In this case, the engine goes into generator mode and works as a regenerative brake with electric power output to the grid. This mode of operation for the engine and gearbox is abnormal and comes with a sharp decrease in the efficiency of the gearbox and engine. The change of torque on the crank shaft of the gearbox - and, consequently, on the motor shaft - in an unbalanced pumping unit occurs sinusoidally.

To equalize the load on the gearbox and engine during one cycle of work, and to reduce the engine power needed to carry out the balancing process, which involves loading the gearbox and engine during the course of the downward drive with additional balance weights, installed either on the balancer or on the cranks and the balancer, which accumulates the energy received from the engine during the course of the rod column's upstroke and releases it during the course of the rod's downstroke.

\section{Structural features of the new construction design for beamless sucker-rod pumping units}

Existing technology for balancing pumping units can cause significant fatigue to ground equipment units due to the high load on the drive of the pumping unit. This leads to premature failure and increased energy consumption. These facts necessitate the search for new, improved designs for sucker-rod pumping units, one of which is the use of a beamless rocking machine for sucker-rod pumping units, developed at the Department of Machine Design at Azerbaijan Technical University (EAPO authorship certificate no. 032268) (Abdullaev et al., 2019).

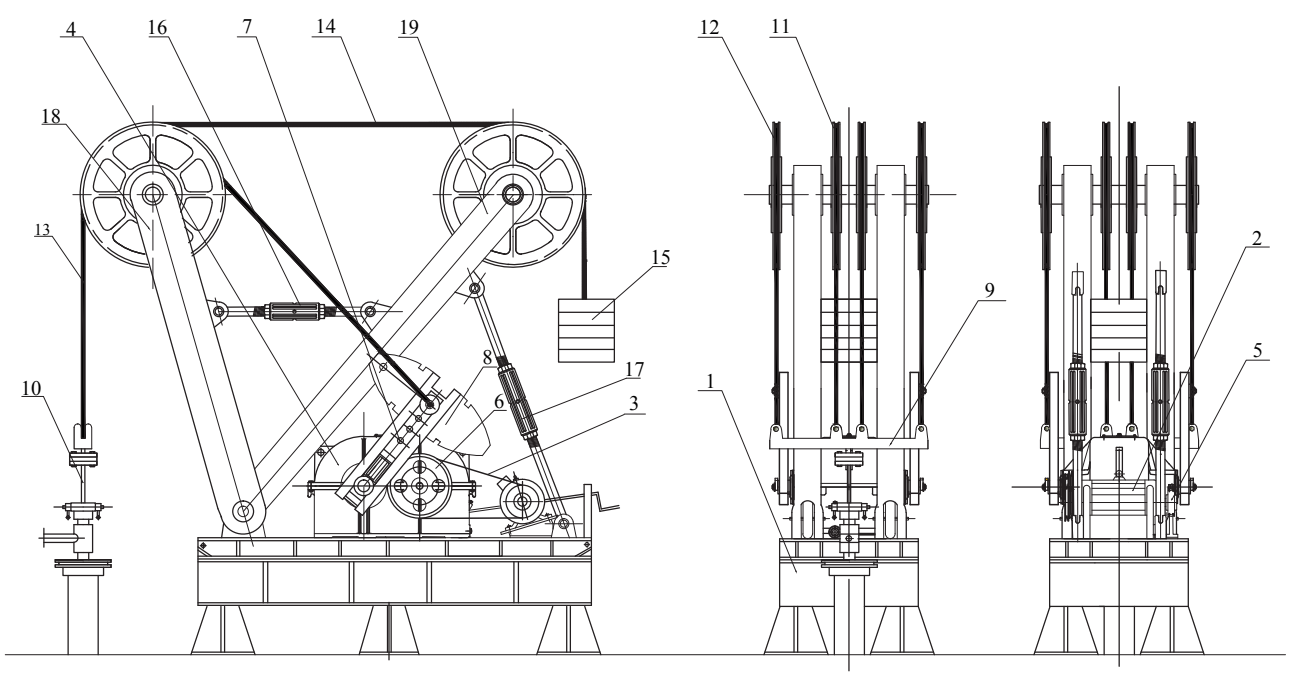

Fig. 1. Diagram of a new solution for a beamless sucker-rod pumping unit Rys. 1. Schemat nowego rozwiązania zespołu pompy żerdziowej bez żurawia

Figure 1 shows a diagram of a new solution for a beamless sucker-rod pump. The new solution of the beamless sucker-rod pump contains two cranks (7), rigidly fixed on both sides at the output ends of the driven shaft of the multi-stage AN-reducer (4), which has only two shafts and gear ratio of $1: 125$. At one end of the drive shaft of the AN-reducer, a stepped driven pulley (6) of the V-belt drive (3) is installed, and at the other output end, a two-disk brake (5) is located.

The mechanical drive is comprised of a frame (1) made of profile rolling in the form of two longitudinal cross-members, two brackets for connecting the front pillars (18), two brackets for connecting the rear pillars (19), two brackets for connecting the front rods (16), and two brackets for connecting the rear rods (17). On the frame, together with an "Abdullaev-Najafov" reducer (AN-reducer) a three-phase asynchronous electric motor (2) is installed. 
As part of the transforming mechanism of mechanical drive, there are also cables $(13,14)$ and blocks $(11,12)$. At one end of the parallel cables, a cross-piece 9 is suspended, from which the rod column (10) is fixed, and at the other end the cranks and a counterweight (8) are fixed. On the other hand, with the parallel cables (14), the traverse is connected to a movable counterweight (15), providing reinforcement.

The lower end of the rod column (10), rigidly connected to the traverse, is connected to the pump piston. The front and rear drive racks, pivotally connected to the frame brackets, are interconnected by front traction bars on the left and right. In addition, the rear pillars are also pivotally connected to the frame brackets with the help of the rear traction rods.

The front and rear traction rods provide a change in the angles of inclination of the front and rear racks. These racks can be made telescopic to adjust the height of the stand depending on the stroke of the rod suspension. The lower ends (base) of the front and rear pillars are attached to the bracket on the hinged support with the option of deflecting them to the right or left with the front rods to free space around the wellhead while making repairs and to precisely control the trajectory of the rod's suspension point along the vertical axis. In addition, the connection of the pillars to the bracket on the hinged support makes it possible to completely unfold the front and rear racks of mechanical drive during transportation to the installation site. To reduce the load on the elements of the transforming mechanism by means of a flexible link to the traverse, a movable counterweight is additionally secured.

A combination of balancing which consists of movable and rotary counterweights is applied in the proposed design to balance the pumping unit. The rotor counterweights are mounted on cranks, and the movable counterweight is connected by a flexible cable to the crosshead of the column. Installation of the movable portion of the counterweight compensates for constant loading at the rod suspension point string due to the weight of the liquid in the rods, thus significantly reducing the load on the cranks and hence to the shafts of the gearbox. This prevents wear on the machine rocking nodes.

\section{The combined balancing of the new construction design for beamless sucker-rod pumping units}

Determining the weight and location of the counterweights is a process which is called balancing. The work of the pumping unit is accompanied by the reciprocating movement of the rod string. One of the most important tasks is to determine the work that the engine must perform during one cycle of the pumping unit - during the rod column's up and down movement.
In this case, the forces of friction and the inertial force component are neglected.

Then, when the rod column moves up, the static load at the rod suspension point can be determined by the formula (Abdullaev et al., 2016):

$$
G_{u p}=G_{r o d}+G_{f l}
$$

and when moving downward by the formula

$$
G_{d w}=G_{r o d}
$$

where:

$G_{r o d}$ - is the force of gravity of the rod column, and $G_{f l}-$ is the weight of fluid above the plunger.

When the rod moves up, the work that needs to be spent is used on raising the liquid column (doing useful work) and raising the rod column (increasing its potential energy):

$$
A_{u p}=\left(G_{r o d}+G_{f l}\right) S_{E}-G_{c w} S_{c}-G_{r} S_{r}
$$

where:

$G_{r}$ - is the weight of the rotor load,

$S_{E}$ - is the movement of the rod suspension point $(E)$ from

the lower position $\left(E_{1}\right)$ to the upper position $E_{2}$,

$S_{c}$ - is the downward movement of the movable counter-

weight $G_{c w}$ from point $F_{1}$ to point $F_{2}$, and

$S_{r}$ - is the movement of the center of gravity of the rotor load.

When the rods move down, useful work on raising the reservoir fluid is not done, and accumulated potential energy is released:

$$
A_{d w}=-G_{r o d} S_{E}+G_{c w} S_{c}+G_{r} S_{r}
$$

where:

$S_{E}$ - is the movement of the rod suspension point $(E)$ from

the upper position $E_{2}$ to the lower position $E_{1}$ and $S_{c}$ - is the downward movement of the movable counterweight $G_{c w}$ from point $F_{2}$ to point $F_{1}$.

According to the basic theory of a sucker-rod pump's operation, the ideal condition for balancing is equality of the pumping unit's operation when the rod suspension point moves up and down $\left(A_{u p}=A_{d w}\right)$.

By equating the expressions of work in the course of up and down movement, we find:

$$
\left(G_{r o d}+G_{f}\right) S_{E}-G_{c w} S_{c}-G_{r} S_{r}=-G_{r o d} S_{E}+G_{c w} S_{c}+G_{r} S_{r}
$$

then

$$
2\left(G_{r o d}+\frac{G_{f l}}{2}\right) S_{E}-2 G_{c w} S_{c}-2 G_{r} S_{r}=0
$$

If we consider that $S_{E}=S_{c} \approx 2 r$ and $S_{r}=2 R$, then we get

$$
r\left(G_{r o d}+\frac{G_{f l}}{2}\right)-G_{c w} r-G_{r} R=0
$$


where $R$ is the distance from the crank rotation axle to the center of gravity of the rotor load.

As the weight of the rotary loads $\left(G_{r}\right)$ placed on the crank is standard, the weight of moving loads can be calculated as follows:

$$
G_{c w}=\left(G_{r o d}+\frac{G_{f l}}{2}\right)-\frac{R}{r} G_{r}=0
$$

Or, given the weight of the movable counterweight, the desired value of the load on the rotor can be determined:

$$
G_{r}=\frac{r}{R}\left(G_{r o d}+\frac{G_{f l}}{2}-G_{c w}\right)
$$

Taking the standard value of the rotor load $\left(G_{r}\right)$ by moving it around the crank, we can determine the best place to install it with the formula:

$$
R=\frac{r}{G_{r}}\left(G_{r o d}+\frac{G_{f l}}{2}-G_{c w}\right)
$$

With the combined balancing of pumping units, the unresolved question remains: which part of the balancing is driven by movable counterweights, and which by rotary ones? Therefore, using the formula to determine the value of the rotor load with the combined equation, we determine the proportion of movable and rotary counterweights:

$$
\frac{R G_{r}}{r\left(G_{r o d}+\frac{G_{f l}}{2}\right)}+\frac{G_{c w} \cdot C-M_{m d}}{C\left(G_{r o d}+\frac{\Delta G_{f l}}{2}\right)}=1
$$

where:

$M_{m d}$ - is the sum of the moments of the weights of the individual parts of the pumping unit relative to the support of the front pillars and $c-$ is the distance from the support of the front pillars to the line of action of the force of the movable counterweight.

In this formula, the first term is the share of the rotor, while the second is the movable counterweight.

\section{Determination of dynamic forces in an unbalanced pumping unit}

To determine the dynamic forces, we consider their action at point $E$, the rod column suspension point, to the traverse of the pumping unit (Fig. 2).

By denoting the dynamic forces at point $E$ during the course of the upward movement of the rod suspension point $G_{E d y n}$ and during the downward movement $G_{E d y n}^{\prime}$, and considering the action of dynamic forces:

$$
\begin{gathered}
G_{E d y n}=m a_{E}=\frac{G_{r o d}+G_{f l}}{g} a_{E}=\frac{a_{E}}{g}\left(G_{r o d}+G_{f l}\right) \\
G_{E d y n}^{\prime}=m^{\prime} a_{E}=\frac{G_{r o d}}{g} a_{E}=\frac{a_{E}}{g} G_{r o d}
\end{gathered}
$$

where:

$a_{E}-$ is the acceleration of the rod suspension point and $g-$ is gravitational acceleration.

In many problems of the dynamics of transforming mechanisms of the pumping unit, it is more convenient to use relationships in which the movement of the rod suspension point $S_{E}$ is a function of the angle of rotation of the crank $\varphi$ according to the dimensionless kinematic parameter $\lambda$ and the relative eccentric $\varepsilon[8-10]$.

For the studied beamless pumping unit, the movement of the rod suspension point is determined by the formula

$$
S_{E}=r\left[1-\cos \varphi+\frac{\lambda}{4}(1-\cos 2 \varphi)+\varepsilon \lambda \sin \varphi-\frac{\varepsilon^{2} \lambda^{2}}{2(1+\lambda)}+\frac{\lambda \varepsilon^{2}}{2}\right]
$$

or

$$
S_{g}=r\left(2+\frac{\varepsilon^{2} \lambda^{2}}{\left(1-\lambda^{2}\right)}+\frac{\varepsilon^{4} \lambda^{4}\left(\lambda^{2}+3\right)}{4\left(1-\lambda^{2}\right)^{3}}\right)
$$

where:

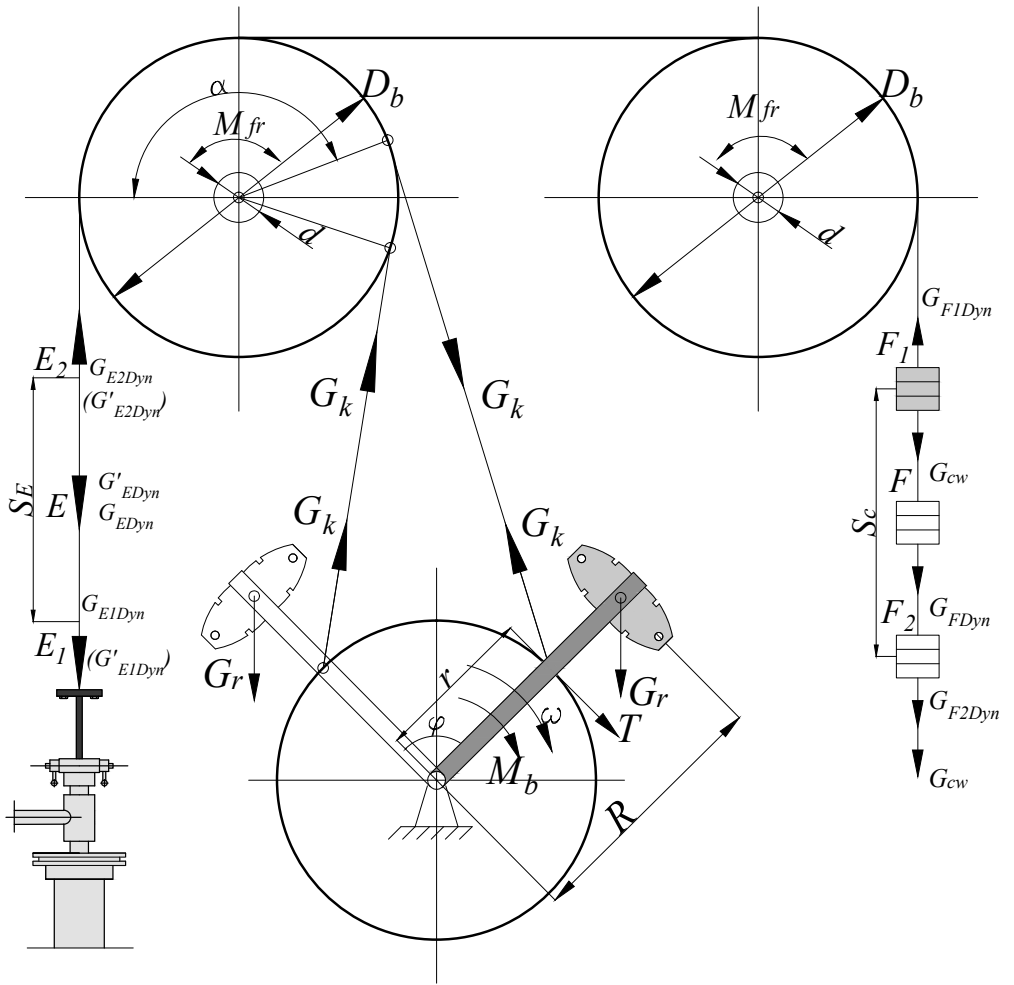

Fig. 2. A diagram of the dynamic forces in a sucker-rod pump

Rys. 2. Schemat działania sił dynamicznych w pompie żerdziowej 
$\omega$ is the angular velocity of the crank, $\varphi$ is angle of crank rotation,

$\lambda=\frac{r}{l}$ is the dimensionless kinematic constant, which characterizes the relationship of the crank radius to the length of the working part of the cable of the pumping unit,

$\varepsilon=\frac{E}{r}$ is the relative eccentricity, and

$E$ is the deaxial value.

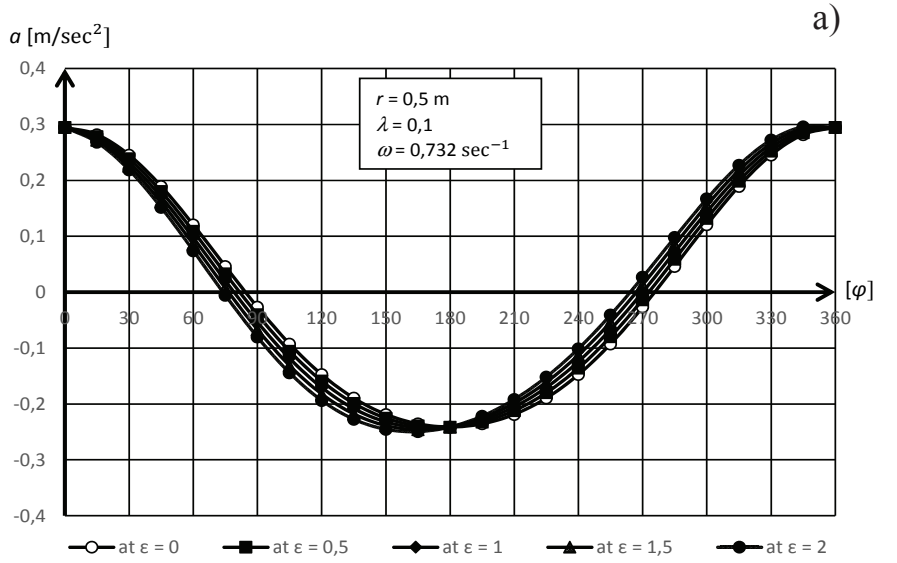

$a\left[\mathrm{~m} / \mathrm{sec}^{2}\right]$

b)

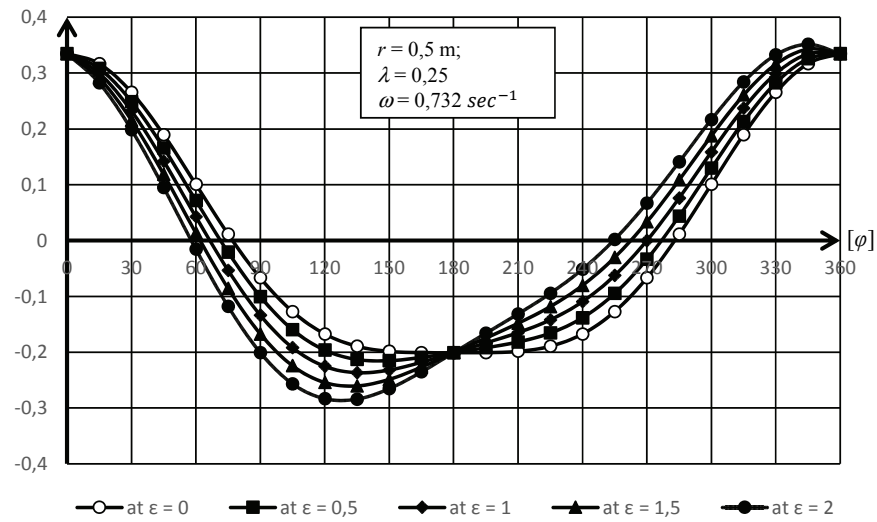

$a\left[\mathrm{~m} / \mathrm{sec}^{2}\right]$

c)

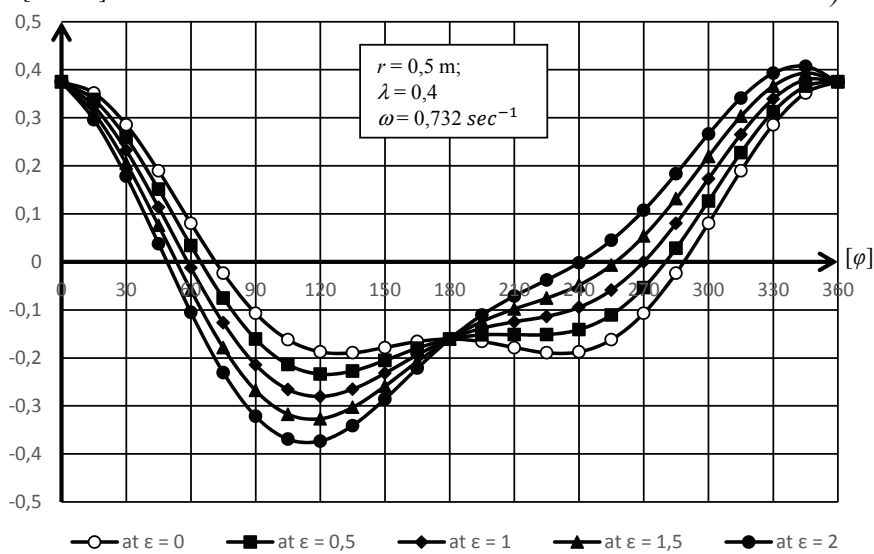

Fig. 3. Graphs of the acceleration of the rod suspension point $\left(a_{E}\right)$ on the angle of rotation of the crank $(\varphi)$

Rys. 3. Wykresy przyspieszenia punktu zawieszenia żerdzi $\left(a_{E}\right)$ od kąta obrotu korby $(\varphi)$
In pumping units with the same $r$ and $\lambda$, the movement of the rod suspension point in the deaxial mechanisms is slightly larger than in the case of axial ones.

On the basis of the calculations carried out by Equation 14 for the new construction design of a beamless sucker-rod pump, it was found that if in the axial mechanism $(\varepsilon=0)$ the maximum piston stroke is almost equal to $2 r$, then with large disaggerations, it can increase almost to $3 r$. This is due to the fact that the greatest movement of the piston is achieved not at $\varphi=180^{\circ}$, but at $\varphi=165^{\circ}-135^{\circ}$.

The acceleration of the rod suspension point for the new construction design for a beamless sucker-rod pump is defined by the following expression:

$$
a_{E \max }=r \omega^{2}[\cos \varphi+\lambda \cos 2 \varphi-\varepsilon \lambda \sin \varphi]
$$

Consider how the acceleration of the rod suspension point on the upstroke and downstroke depends on the crank angle $\varphi$.

Fig. 3 shows a plot of the acceleration of the rod suspension point on the angle of rotation of the $\operatorname{crank}(\varphi)$ for $r=0.5 \mathrm{~m}$, $\omega=0.732 \mathrm{sec}^{-1}$ with different values of the dimensionless kinematic constant $\lambda$, the ratio of the length of the crank to the length of the working part of the cable, and the relative eccentric $\varepsilon$.

As can be seen from Fig. 3a, with a relative eccentricity $\varepsilon=0$ (axial mechanism), the extreme value of acceleration is obtained by turning the crank by $\varphi=0^{\circ}$ and $\varphi=180^{\circ}$.

However, as both the relative eccentricity and the dimensionless kinematic constant increase, the acceleration of the rod suspension point increases and the crank angle in relation to this value (the mechanism is deaxial). As shown in the graphs, when $\lambda=0.25$ and $\varepsilon=2$, the maximum values of acceleration are not obtained when $\varphi=0^{\circ}$ and $\varphi=180^{\circ}$, but when turning the crank to $\varphi=127^{\circ} 46^{\prime}$ and $\varphi=345^{\circ} 46^{\prime}$ (Fig. 3b).

When $\lambda=0.4$ and $\varepsilon=2$, the acceleration of the rod suspension point increases sharply and the angle of rotation of the crank changes to this value. As can be seen from the graphs, the maximum value of the acceleration of the rod suspension point in this case is obtained when the angle of rotation of the crank is $\varphi=113^{\circ} 50^{\prime}$ and $\varphi=342^{\circ} 25^{\prime}$ (Fig. 3c).

We can analytically determine the angles of rotation of the crank $\varphi$ at which the maximum acceleration of the piston $a_{E}$ is obtained by equating the derivative $\varphi$ from the right side of the equation to zero:

$$
\frac{d a_{E}}{d \varphi}=r \omega^{2}(-\sin \varphi-2 \lambda \sin 2 \varphi-\varepsilon \lambda \cos \varphi)
$$

when we get

$$
\sin \varphi+4 \lambda \sin \varphi \cos \varphi+\varepsilon \lambda \cos \varphi=0
$$

Expressing the trigonometric function sine through the tangent of the half argument, we get 
Table 1. The values of the acceleration of the rod suspension point and the angles of rotation of the crank corresponding to this value for different values of $\lambda$ and $\varepsilon$

Tabela 1. Wartości przyspieszenia punktu zawieszenia żerdzi oraz odpowiadających im kątów obrotu korby dla różnych wartości $\lambda$ i $\varepsilon$

\begin{tabular}{|c|c|c|c|}
\hline$\lambda$ & $\varepsilon$ & $\varphi$ & $a_{E \max }\left[\mathbf{m} / \mathbf{s}^{2}\right]$ \\
\hline 0.10 & $\begin{array}{l}0.5 \\
1.0 \\
1.5 \\
2.0\end{array}$ & 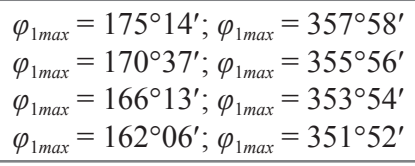 & $\begin{array}{l}a_{\text {max }}=-0.2417 ; a_{\text {max }}=0.2949 \\
a_{\text {max }}=-0.2433 ; a_{\text {max }}=0.2956 \\
a_{\text {max }}=-0.2460 ; a_{\text {max }}=0.2968 \\
a_{\text {max }}=-0.2497 ; a_{\max }=0.2985\end{array}$ \\
\hline 0.25 & $\begin{array}{l}0.5 \\
1.0 \\
1.5 \\
2.0\end{array}$ & 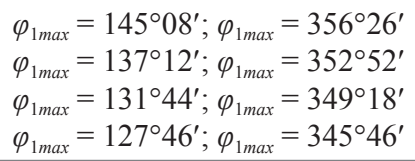 & $\begin{array}{l}a_{\text {max }}=-0.2158 ; a_{\text {max }}=0.3359 \\
a_{\text {max }}=-0.2369 ; a_{\text {max }}=0.3391 \\
a_{\text {max }}=-0.2609 ; a_{\text {max }}=0.3442 \\
a_{\text {max }}=-0.2867 ; a_{\max }=0.3515\end{array}$ \\
\hline 0.40 & $\begin{array}{l}0.5 \\
1.0 \\
1.5 \\
2.0\end{array}$ & $\begin{array}{l}\varphi_{1_{\max }}=122^{\circ} 56^{\prime} ; \varphi_{1_{\max }}=355^{\circ} 36^{\prime} \\
\varphi_{1_{\max }}=119^{\circ} 04^{\prime} ; \varphi_{1_{\max }}=351^{\circ} 12^{\prime} \\
\varphi_{1 \max }=116^{\circ} 08^{\prime} ; \varphi_{1 \max }=346^{\circ} 49^{\prime} \\
\varphi_{1_{\max }}=113^{\circ} 50^{\prime} ; \varphi_{1_{\max }}=342^{\circ} 25^{\prime}\end{array}$ & $\begin{array}{l}a_{\text {max }}=-0.2344 ; a_{\max }=0.3771 \\
a_{\text {max }}=-0.2804 ; a_{\text {max }}=0.3833 \\
a_{\text {max }}=-0.3279 ; a_{\text {max }}=0.3935 \\
a_{\text {max }}=-0.3765 ; a_{\max }=0.4077\end{array}$ \\
\hline
\end{tabular}

$$
\sin \varphi=\frac{2 \operatorname{tg} \frac{\varphi}{2}}{1+\operatorname{tg}^{2} \frac{\varphi}{2}} ; \quad \cos \varphi=\frac{1-\operatorname{tg}^{2} \frac{\varphi}{2}}{1+\operatorname{tg}^{2} \frac{\varphi}{2}}
$$

Replacing $\operatorname{tg} \frac{\varphi}{2}=x$, we get

$$
\begin{aligned}
& \frac{2 x}{1+x^{2}}+4 \lambda\left(\frac{2 x}{1+x^{2}}\right)\left(\frac{1-x^{2}}{1+x^{2}}\right)+\varepsilon \lambda\left(\frac{1-x^{2}}{1+x^{2}}\right)=0 \\
& -\varepsilon \lambda x^{4}+2 x^{3}(1-4 \lambda)+2 x(1+4 \lambda)+\varepsilon \lambda=0
\end{aligned}
$$

If we replace $\varepsilon \lambda=A, 2(1-4 \lambda)=B$, and $2(1+4 \lambda)=C$, we get the following equation of the fourth degree:

$$
A x^{4}-B x^{3}-C x-A=0
$$

To find the roots of this equation, according to the angle of rotation of the $\operatorname{crank} \varphi$ at which the acceleration of the piston $a_{E}$ turns out to be extreme, there are various ways (for example, the method of auxiliary coefficients, Ferrari, Descartes-Euler, Laguerre, or by using an online calculator, introducing the coefficients $A, B$, and $C$ ).

The values of the acceleration of the rod suspension point and the angles of rotation of the crank corresponding to this value for different values of $\lambda$ and $\varepsilon$ are presented in Table 1 .

With the given values of mass and acceleration, we obtain a dynamic force on the upstroke

$$
G_{E d y n}=\frac{G_{r o d}+G_{f l}}{g} r \omega^{2}(\cos \varphi+\lambda \cos 2 \varphi-\varepsilon \lambda \sin \varphi)
$$

Based on the calculations made for a new construction design of a beamless rocking machine, it was found that with different values of relative eccentricity $(\varepsilon=0, \varepsilon=0.5, \varepsilon=1.0$, $\varepsilon=1.5$, and $\varepsilon=2.0)$ and the dimensionless kinematic constant ( $\lambda=0.1, \lambda=0.25$, and $\lambda=0.4$ ) the maximum movement of the rod suspension point is $S_{g}=(2.0 \ldots 3.0) r$, and its maximum acceleration at the highest value of the dimensionless kinematic constant (on rocking machine СКД 2-0,6-250, СКД 4-2,1-1400, СКД 6-2,5-2800, СКД 8-3-4000, СКД 10-3,5-5600, and СКД 12-3-5600 the value of the dimensionless kinematic parameter is $\lambda=0.4)$ changes within $a_{\text {Emax }}=(1.41 \ldots 1.52) r \omega^{2}$.

The dynamic force on the downstroke is

$$
G_{E d y n}^{\prime}=\frac{G_{r o d}}{g} r \omega^{2}(\cos \varphi+\lambda \cos 2 \varphi-\varepsilon \lambda \sin \varphi)
$$

Therefore, with average values of movement $S_{g} \approx 2.5 \mathrm{r}$ and acceleration $a_{E \max } \approx 1.47 r \omega^{2}$, the expression of dynamic force, taking into account Equation 16, will take the following form when going up

$$
G_{E d y n}=\frac{S_{E} \cdot \pi^{2} \cdot n^{2}}{2.5 \cdot 30^{2} g} 1.47\left(G_{r o d}+G_{f l}\right)
$$

and when going down

$$
G_{E d y n}^{\prime}=\frac{S_{E} \cdot \pi^{2} \cdot n^{2}}{2.5 \cdot 30^{2} g} 1.47 G_{r o d}
$$

where $S_{E}$ is the moving rod suspension point and $n$ is the pumping speed of the rocking machine.

Given that the values of $\pi^{2}=9.87$ and $g=9.81$ are approximately equal, they can be reduced. Since $\frac{2.5 \cdot 30^{2}}{1.47}=1530$, the expression dynamic force when going up is

$$
G_{E d y n}=\frac{S_{E} n^{2}}{1530}\left(G_{r o d}+G_{f l}\right)
$$

and when going down is

$$
G_{E d y n}=\frac{S_{E} n^{2}}{1530} G_{r o d}
$$

where $\frac{a_{E}}{g}=\psi_{d}=\frac{S_{E} n^{2}}{1530}$ is the dynamic factor. 
From Equations 25 and 26, it follows that the dynamic factor and dynamic load grow in proportion to the stroke of the stuffing box and the square of the number of double strokes of the pumping unit.

Consider how the dynamic force changes, acting at point $E$ during the up- and downstroke, according to the angle of rotation of crank $\varphi$.

At the beginning of the upstroke, the acceleration of the rod suspension point, and hence of the dynamic forces, with a crank angle of $\varphi_{\max }=0^{\circ}$ (all values of relative eccentricity $\varepsilon=0.5, \varepsilon=1.0, \varepsilon=1.5$, and $\varepsilon=2.0$ ), is positive. Since the force is positive, the dynamic force is directed downwards. At the apex of the point at the end of the upstroke, the dynamic forces at the angles of rotation of the crank $\varphi_{\max }=122^{\circ} 56^{\prime}$ (at $\varepsilon=0.5$ ), $\varphi_{\max }=119^{\circ} 04^{\prime}$ (at $\left.\varepsilon=1.0\right), \varphi_{\max }=116^{\circ} 08^{\prime}$ (at $\varepsilon=1.5$ ), and $\varphi_{\max }=113^{\circ} 50^{\prime}($ at $\varepsilon=2.0)$ are negative. This shows that dynamic efforts are directed from the bottom up.

As follows from Fig. 3, the acceleration of the rod suspension point, and consequently of the dynamic forces, with a crank angle of rotation $\varphi_{\max }=64^{\circ} 28^{\prime}$ and $\varphi_{\max }=280^{\circ} 14^{\prime}$ (at $\varepsilon=0.5$ ), $\varphi_{\max }=58^{\circ} 30^{\prime}$ and $\varphi_{\max }=270^{\circ} 02^{\prime}$ (at $\varepsilon=1.0$ ), $\varphi_{\max }=53^{\circ} 22^{\prime}$ and $\varphi_{\max }=257^{\circ} 00^{\prime}($ at $\varepsilon=1.5)$, and $\varphi_{\max }=49^{\circ} 33^{\prime}$ and $\varphi_{\max }=240^{\circ} 42^{\prime}$ (at $\varepsilon=2.0$ ) is zero (the speed reaches the maximum value at the same time).

Consider the change in the dynamic forces at point $E$ on the downstroke.

For the beginning of the downstroke at angles of rotation of the crank $\varphi_{\max }=122^{\circ} 56^{\prime}$ (at $\left.\varepsilon=0.5\right), \varphi_{\max }=119^{\circ} 04^{\prime}$ (at $\varepsilon=1.0$ ), $\varphi_{\max }=116^{\circ} 08^{\prime}$ (at $\left.\varepsilon=1.5\right)$, and $\varphi_{\max }=113^{\circ} 50^{\prime}$ (at $\varepsilon=2.0$ ), the dynamic forces have are negative.

At the end of the downstroke for crank angles $\varphi_{\max }=355^{\circ} 36^{\prime}$ (at $\varepsilon=0.5), \varphi_{\max }=351^{\circ} 12^{\prime}$ (at $\left.\varepsilon=1.0\right), \varphi_{\max }=346^{\circ} 49^{\prime}$ (at $\varepsilon=1.5$ ), and $\varphi_{\max }=342^{\circ} 25^{\prime}$ (at $\varepsilon=2.0$ ), the dynamic force reaches its maximum value and is positive.

The criterion for estimating the operating mode of an installation is the dynamic similarity parameter, called the Cauchy parameter, $C_{a}[11]$ :

$$
C_{a}=\frac{\omega H}{v_{s}}
$$

where:

$\omega$ is the angular velocity of the crank,

$H$ is the length of the rod column (pump shutter depth) and $v_{s}$ is the velocity of sound in the rod column.

For static and dynamic operating modes of the separation unit, the Cauchy parameter may be used. Obviously, for such a separation it is necessary to take a certain (boundary) numerical value of the Cauchy parameter. For this we use the equation of dynamic factor.

It is known that an arbitrary increase in the frequency of double strokes leads to an excess of the inertial acceleration $a_{E}$ over the acceleration of free fall $\mathrm{g}$, and that the dynamic factor becomes more than 1, which sharply increases the accident rate of the rod string. Therefore, when designing plant operation modes, the pumping speed at which the ratio of accelerations is 1 is usually considered critical:

$$
\frac{a_{E}}{g}=\frac{S_{g} n^{2}}{1530} \leq 1
$$

Then the frequency of double strokes of the pumping unit will be as follows:

$$
n_{k r}=\sqrt{\frac{1530}{S_{E}}}=39.12 \sqrt{\frac{1}{S_{E}}}
$$

If we take speeds not exceeding $50-75 \%$ of the critical speed to be acceptable, then the maximum allowable speed will be

$$
n_{\max }=19.56 \ldots 29.34 \sqrt{\frac{1}{S_{E}}}
$$

We know that $n^{2}=\frac{\left(19.56^{2} \ldots 29.34^{2}\right)}{S_{E}}$ and $S_{E} n^{2}=\left(19.56^{2} \ldots 29.34^{2}\right)$, so the maximum permissible dynamic factor will be

$$
\psi_{d}=\frac{S_{E} n^{2}}{1530}=\frac{\left(19.56^{2} \ldots 29.34^{2}\right)}{1530}=0.25 \ldots 0.56
$$

If $\psi_{d}<0.4$, then the operating mode of the pumping unit will be static; if $\psi_{d}>0.4$, then the operating mode of the installation is dynamic. The calculations show that for the most common operating conditions of pumping units during well operation, the boundary value of the Cauchy parameter can be approximately assumed to be $\psi_{d}=0.4$.

\section{Determination of dynamic forces in combined balancing}

As already noted, in combined balancing the counterweight is set as a movable counterweight and on a crank. When the rotary loads are located on the crank, their inertial forces are loaded only on the bearings of the crank shaft and, at its constant angular velocity of rotation, these forces are not transmitted to other parts of the unit. Therefore, we consider only inertial forces creating movable counterweights.

As can be seen from Figure 2, a static force is applied at point $F$, directed vertically downwards along the upstroke and downstroke and equal to the weight of the movable counterweight $G_{c w}$. Therefore, the mass acting at point $F$ during the up and down stroke will be equal to:

$$
m=\frac{G_{c w}}{g}
$$


As can be seen from Figure 2, the maximum acceleration of point $F$ is equal to the acceleration of the rod suspension point. Given that $S_{E}=S_{c}$, then the dynamic force $\mathrm{F}$ at a point on the upstroke and downstroke is

$$
\begin{aligned}
& G_{F d y n}=m a_{F}=\frac{G_{c w}}{g} a_{F}=\frac{S_{E} n^{2}}{1530} G_{c w} \\
& G_{F d y n}^{\prime}=m^{\prime} a_{F}=\frac{G_{c w}}{g} a_{F}=\frac{S_{E} n^{2}}{1530} G_{c w}
\end{aligned}
$$

i.e., $G_{F d y n}=G_{F d y n}^{\prime}$.

Consider how the dynamic force changes at point $F$ during the up- and downstroke of the unit depending on the angle of rotation of the $\operatorname{crank} \varphi$. To do this, we bring it to a form similar to that for point $E$ :

$$
G_{F d y n}=G_{F d y n}^{\prime}=\frac{S_{E} n^{2}}{1530} G_{c w}
$$

The peculiarity of the dynamic effort change in the length of time for the up- and downstroke will be a decrease of $G_{F d y n}$ from the maximum to zero and further: it will transition to the region of negative values.

And although at the angle of rotation of the $\operatorname{crank} \varphi_{\max }=0^{\circ}$, $\cos \varphi=1-$ the dynamic force, the force of inertia - is in the opposite direction of the movement; from the bottom up, it has a negative value during the entire upward stroke:

$$
G_{F d y n}^{\prime}=-\frac{S_{E} n^{2}}{1530} G_{c w}
$$

At the beginning of the downstroke (at point $F_{2}$ ) with angles of crank rotation of $\varphi_{\max }=122^{\circ} 56^{\prime}$ (at $\varepsilon=0.5$ ), $\varphi_{\max }=119^{\circ} 04^{\prime}$ (at $\varepsilon=1.0$ ), $\varphi_{\max }=116^{\circ} 08^{\prime}$ (at $\varepsilon=1.0$ ), and $\varphi_{\max }=113^{\circ} 50^{\prime}$ (at $\varepsilon=2.0$ ), the dynamic forces are negative. Then the equation for dynamic force at the start of the downstroke will be

$$
G_{F 2 d y n}=-\frac{S_{E} n^{2}}{1530} G_{c w}
$$

Since in this case the force is positive and directed downwards, for the whole downstroke it is

$$
G_{F d y n}=-\frac{S_{E} n^{2}}{1530} G_{c w}
$$

This defines the maximum efforts at points $E$ and $F$, which are composed of static and dynamic components. The maximum force at point $E$ for the up- and downstroke will take the following form:

$$
G_{E}=G_{E s t}+G_{E d y n} ; \quad G_{E}^{\prime}=G_{E s t}^{\prime}+G_{F d y n}^{\prime}
$$

Similarly, the maximum force at point $F$ for the up- and downstroke will be

$$
G_{F}=G_{F s t}+G_{F d y n} ; \quad G_{F}^{\prime}=G_{F s t}^{\prime}+G_{F d y n}^{\prime}
$$

Substituting all the values of static and dynamic forces at point $E$, we get

$$
\begin{aligned}
G_{E m a x} & =G_{E s t}+G_{E d y n}=\left(G_{r o d}+G_{f l}\right)+\left(G_{r o d}+G_{f l}\right) \frac{S_{E} n^{2}}{1530}= \\
& =\left(G_{r o d}+G_{f l}\right)\left(1+\frac{S_{E} n^{2}}{1530}\right) \\
G_{E \max }^{\prime} & =G_{E s t}^{\prime}+G_{E d y n}^{\prime}=G_{r o d}+G_{r o d} \frac{S_{E} n^{2}}{1530}=G_{r o d}\left(1+\frac{S_{E} n^{2}}{1530}\right)
\end{aligned}
$$

where $\left(1+\frac{S_{E} n^{2}}{1530}\right)=k_{d}$ is the dynamic coefficient.

Similarly, at point $F$

$$
G_{F s t}=G_{F s t}^{\prime}=G_{c w} ; \quad G_{F d y n}=G_{F d y n}^{\prime}=-\frac{S_{E} n^{2}}{1530} G_{c w}
$$

Finally,

$$
G_{F}=G_{F}^{\prime}=G_{c w}+\left(-\frac{S_{E} n^{2}}{1530} G_{c w}\right)=G_{c w}\left(1-\frac{S_{E} n^{2}}{1530}\right)
$$

\section{Determination of dynamic forces in the elastic cable of a pumping unit when it is accelerating (we ignore the force of the weight of the cable)}

Dynamic calculations of the pumping unit conversion mechanism significantly increase the accuracy of the actual load. When starting the pumping unit on a cable, additional dynamic loads arise due to the acceleration of the rod suspension point. Since the hoisting cable is elastic, dynamic loads arise in it, which are of an oscillatory nature and which increase with increased pumping depth.

As is known, the torque on the output shaft of the gear changes according to the force in the cable converting mechanism. This force changes during one cycle, based on the angle of rotation of the crank, $\varphi$. Therefore, we define the force in the cable of the transforming mechanism when the rod suspension point moves down and up. To determine the force in the cable applied to the crank of the transforming mechanism when the suspension point moves up, we determine the torque relative to the axis of rotation of the block (Fig. 4a):

$$
\sum M_{D}=0 ;-G_{u p} \frac{D_{b}}{2}-M_{f r}+G_{k} \frac{D_{b}}{2}+G_{c w}^{*} \frac{D_{b}}{2}=0
$$

The force in the cable is defined as follows:

$$
G_{k}=G_{u p}+\frac{2 M_{f r}}{D_{b}}-G_{c w}^{*}
$$




\section{NAFTA-GAZ}

where $G_{u p}$ is the force acting on the rod suspension point when it moves up:

$G_{u p}=G_{r o d}+G_{f l}+G_{r o d}^{i n}+G_{f l}^{i n}=G_{r o d}+G_{f l}+\left(G_{r o d}+G_{f l}\right) \frac{S_{E} n^{2}}{1530}$ and

$G_{c w}^{*}$ is the total force from the weight of the movable counterweight when the suspension point moves up:

$$
G_{c w}^{*}=G_{c w}+G_{c w}^{i n}=G_{c w}-\frac{S_{E} n^{2}}{1530} G_{c w}
$$

Then,

$G_{k}=G_{r o d}+G_{f l}+\left(G_{r o d}+G_{f l}\right) \frac{S_{E} n^{2}}{1530}+\frac{2 M_{f r}}{D_{b}}-\left(G_{c w}-\frac{S_{E} n^{2}}{1530} G_{c w}\right)$

where $M_{f r}$ is the friction torque in the axle block

$$
M_{f r}=2 G_{u p} \sin \frac{\alpha}{2} f \frac{d}{2}
$$

where:

$\alpha$ is the cable wrap angle block,

$f$ is the coefficient of friction in the bearings of the block, and $d$ is the diameter of the block pin.

Then, taking into account Equation 44 and the dynamism factor, the force in the cable is determined as follows:

$$
G_{k}=\left(G_{r o d}+G_{f}\right) k_{1}-G_{c w}+\psi_{d}\left(\left(G_{r o d}+G_{f f}\right) k_{1}+G_{c w}\right)
$$

where $k_{1}=\left(1+2 \sin \frac{\alpha}{2} f \frac{d}{D_{b}}\right)$

If we consider following

$$
\begin{gathered}
\left(G_{r o d}+G_{f}\right) k_{1}-G_{c w}=G_{k 1 u p} \\
\psi_{d}\left(\left(G_{r o d}+G_{f f}\right) k_{1}+G_{c w}\right)=G_{k 2 u p}
\end{gathered}
$$

Then,

$$
G_{k}=G_{k 1 u p}+G_{k 2 u p}
$$

Here the first terms of the sum $\left(G_{k 1 u p}\right)$ reflect the change of static forces, and the second sum $\left(G_{k 2 u p}\right)$ represents the dynamic forces.

The force in the cable applied to the crank of the transforming mechanism when the rod suspension point moves down (Fig. 4b) is

$$
\sum M_{D}=0 ;-G_{d o w n} \frac{D_{b}}{2}+M_{f r}-G_{\kappa} \frac{D_{b}}{2}+G_{c w}^{*} \frac{D_{b}}{2}=0
$$

Then the force in the cable

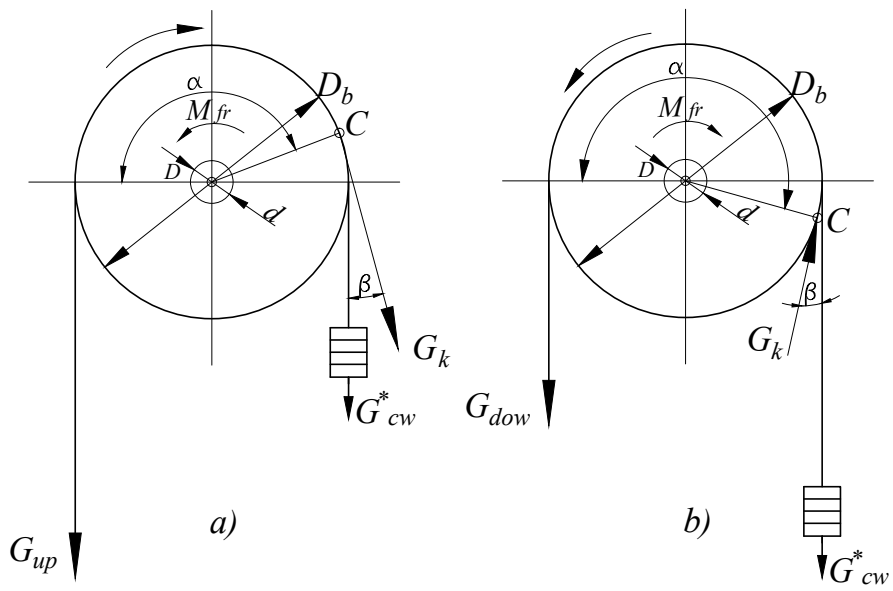

Fig. 4. The action of forces in the pumping unit

Rys. 4. Schemat działania sił w zespole pompowym

$$
G_{k}=-G_{d o w n}+\frac{2 M_{f r}}{D_{b}}+G_{c w}^{*}
$$

where $G_{\text {down }}$ is the force acting on the rod suspension point when it moves down,

$$
G_{d o w n}=G_{r o d}+G_{\text {rod }}^{i n}=G_{r o d}+G_{r o d} \frac{S_{E} n^{2}}{1530}
$$

$G_{c w}^{*}$ is the force from the weight of the movable counterweight when the rod suspension point moves down:

$$
G_{c w}^{*}=G_{c w}-\frac{S_{E} n^{2}}{1530} G_{c w}
$$

Then the force in the cable when the rod suspension point moves down is

$$
\begin{aligned}
G_{k} & =-\left(G_{r o d}+G_{r o d} \frac{S_{E} n^{2}}{1530}\right)+\frac{2 M_{f r}}{D_{b}}+\left(G_{c w}-\frac{S_{E} n^{2}}{1530} G_{c w}\right)= \\
& =-G_{r o d} k_{2}+G_{c w}-\psi_{d}\left(G_{r o d} k_{2}+G_{c w}\right)
\end{aligned}
$$

where $k_{2}=\left(1-2 \sin \frac{\alpha}{2} f \frac{d}{D_{b}}\right)$.

If we consider following

$$
\begin{gathered}
-G_{r o d} k_{2}+G_{c w}=G_{k 1 d o w n} \\
-\psi_{d}\left(G_{r o d} k_{2}+G_{c w}\right)=G_{k 2 d o w n}
\end{gathered}
$$

then

$$
G_{k}=G_{k 1 \text { down }}+G_{k 2 \text { down }}
$$

Here, the first terms of the sum $\left(G_{k 1 \text { down }}\right)$ reflect the change of static forces, and the second sum $\left(G_{k 2 d o w n}\right)$ represents the dynamic forces. 


\section{Results}

1. Based on the analytical dependencies obtained, it has been proven that changes in the magnitude of dynamic loads in one cycle at the given geometrical values of the pumping unit and its mode of operation depend not only on the angle of rotation of the crank, $\varphi$, but also on the dimensionless kinematic parameter $\lambda$ and the relative eccentricity $\varepsilon$.

2 . It has been established that the maximum value of dynamic loads at $\varepsilon=0$ and $\lambda=0.1$ is reached at the angle of rotation of the crank $\varphi=0^{\circ}, 180^{\circ}, 360^{\circ}$. With an increase in the relative eccentricity, the crank rotation angles corresponding to the maximum value of the dynamic forces are $\varphi_{\max }=162^{\circ}-175^{\circ}$, and $\varphi_{\max }=351^{\circ}-357^{\circ}$.

3. With an increase in the dimensionless kinematic parameter $\lambda$, the maximum value of dynamic loads increases sharply. Since at $\lambda=0.25$, the angles of rotation of the crank corresponding to the maximum value of the dynamic forces are $\varphi_{\max }=127^{\circ}-145^{\circ}$ and $\varphi_{\max }=345^{\circ}-356^{\circ}$, and at $\lambda=0.4$ it is $\varphi_{\max }=113^{\circ}-122^{\circ}$ and $\varphi_{\max }=342^{\circ}-355^{\circ}$.

4. The proposed analytical expressions allow us to determine the value of the maximum dynamic force at the rod suspension point, depending on the value of the static load.

5. According to the proposed methodology, the theoretical maximum load acting at the rod suspension point of a new construction design for a beamless pumping unit with combined balancing has been calculated.

6. Analytical equations have been proposed to determine the additional dynamic forces in the elastic cable of the transforming mechanism of the pumping unit when the rod suspension point moves up and down with a given acceleration.

7. The results of the calculations can serve as a guide in determining the maximum load acting at the rod suspension point and in selecting the appropriate size of the pumping unit.

\section{List of abbreviations}

AN-reducer - "Abdullaev-Najafov" reducer - a threestage gearbox which is constructed with only two shafts with a gear ratio of 1:125 (Eurasian Patent Organization, patent no. 017053);

СКД Х-XX-XXX - by ОСТ 26-16-08-87 (Industry standards) - in Russian this stands for "станок-качалка дезаксиальный," “a deaxial pumping unit". Further, X - the rated load on the rod suspension point; $\mathrm{XX}$ - maximum stroke length of the rod suspension point; and $\mathrm{XXX}$ - the rated torque on the driven shaft of the gearbox.

\section{Nomenclature}

\begin{tabular}{|c|c|c|c|}
\hline № & Designation & $\begin{array}{c}\text { Unit of } \\
\text { measurement }\end{array}$ & Definition \\
\hline 1 & $G_{r o d}$ & $\mathrm{~N}$ & the force of gravity of the rod column \\
\hline 2 & $G_{c w}$ & $\mathrm{~N}$ & the weight of the movable counterweight \\
\hline 3 & $G_{f l}$ & $\mathrm{~N}$ & the weight of the fluid above the plunger \\
\hline 4 & $G_{\text {in }}$ & $\mathrm{N}$ & the sum of the inertial force of the rod column and the fluid above the plunger \\
\hline 5 & $G^{\text {in }}{ }_{\text {rod }}$ & $\mathrm{N}$ & the inertial force of rod column \\
\hline 6 & $G_{f l}^{i n}$ & $\mathrm{~N}$ & the inertial force of the fluid above the plunger \\
\hline 7 & $G_{u p}$ & $\mathrm{~N}$ & the static load at the rod suspension point when the rod column moves upward \\
\hline 8 & $G_{d w}$ & $\mathrm{~N}$ & the static load at the rod suspension point when the rod column moves downward \\
\hline 9 & $G_{F}$ & $\mathrm{~N}$ & the maximum force at point $\mathrm{f}$ during the upstroke \\
\hline 10 & $G_{E d y n}$ & $\mathrm{~N}$ & the dynamic forces at point e during the course of the upward movement of the rod suspension point \\
\hline 11 & $G_{E d y n}^{\prime}$ & $\mathrm{N}$ & the dynamic forces at point e during the course of the downward movement of the rod suspension point \\
\hline 12 & $G_{F 2 d y n}$ & $\mathrm{~N}$ & the dynamic force expression for the start of the downstroke \\
\hline 13 & $G_{E}, G_{E}^{\prime}$ & $\mathrm{N}$ & the maximum force at point e for the up- and downstroke \\
\hline 14 & $\mathrm{G}_{\mathrm{k}}$ & $\mathrm{N}$ & the force in the cable \\
\hline 15 & $\mathrm{G}_{\text {up }}$ & $\mathrm{N}$ & the force acting on the rod suspension point when it moves upward \\
\hline 16 & $G_{c w}^{*}$ & $\mathrm{~N}$ & the total force from the weight of the movable counterweight when the suspension point moves upward \\
\hline 17 & $\left(G_{k 1 \text { up }}\right)$ & $\mathrm{N}$ & the sums reflect the change in static forces when the rod suspension point moves upward \\
\hline 18 & $\left(G_{k 2 u p}\right)$ & $\mathrm{N}$ & the sums reflect the change in dynamic forces when the rod suspension point moves upward \\
\hline 19 & $\left(G_{k 1 d o w n}\right)$ & $\mathrm{N}$ & the sums reflect the change in static forces when the rod suspension point moves downward \\
\hline 20 & $\left(G_{k 2 d o w n}\right)$ & $\mathrm{N}$ & the sums reflect the change in dynamic forces when the rod suspension point moves downward \\
\hline 21 & $M_{f r}$ & $\mathrm{~N} \cdot \mathrm{m}$ & the friction torque in the axle block \\
\hline 22 & $\alpha$ & degree & the cable wrap angle block \\
\hline 23 & $f$ & - & coefficient of friction in the bearings of the block \\
\hline 24 & $d$ & $\mathrm{~m}$ & diameter of the block pin \\
\hline
\end{tabular}




\begin{tabular}{|c|c|c|c|}
\hline № & Designation & $\begin{array}{l}\text { Unit of } \\
\text { measurement }\end{array}$ & Definition \\
\hline 25 & $A_{u p}, A_{d w}$ & Joule & $\begin{array}{l}\text { the work that the engine must perform during a cycle of the pumping unit - during the rod column's upward } \\
\text { and downward movement }\end{array}$ \\
\hline 26 & $S_{r}$ & $\mathrm{~m}$ & the movement of the center of gravity of the rotor load \\
\hline 27 & $S_{E}$ & $\mathrm{~m}$ & the movement of the rod suspension point $(E)$ from the lower position $F_{1}$ to the upper position $F_{2}$ \\
\hline 28 & $S_{g}$ & $\mathrm{~m}$ & $\begin{array}{l}\text { the movement of the rod suspension point depending on the length of the crank and dimensionless kinematic } \\
\text { parameters }\end{array}$ \\
\hline 29 & $S_{c}$ & $\mathrm{~m}$ & the downward movement of the movable counterweight $G_{c w}$ from point $F_{1}$ to point $F_{2}$ \\
\hline 30 & $n_{k r}$ & $\min ^{-1}$ & the frequency of double strokes of the pumping unit \\
\hline 31 & $n_{\max }$ & $\min ^{-1}$ & maximum allowable number of double strokes of the pumping unit \\
\hline 32 & $R$ & $\mathrm{~m}$ & the distance from the crank rotation axle to the center of gravity of the rotor load \\
\hline 33 & $r$ & $\mathrm{~m}$ & the crank radius \\
\hline 34 & $M_{m d}$ & $\mathrm{~N} \cdot \mathrm{m}$ & $\begin{array}{l}\text { the sum of the moments of the weights of the individual parts of the pumping unit relative to the support of } \\
\text { the front pillars }\end{array}$ \\
\hline 35 & $C$ & $\mathrm{~m}$ & the distance from the support of the front pillars to the line of action of the force of the movable counterweight \\
\hline 36 & $a_{E}$ & $\mathrm{~m} / \mathrm{sec}^{2}$ & the acceleration of the rod suspension point \\
\hline 37 & $g$ & $\mathrm{~m} / \mathrm{sec}^{2}$ & gravitational acceleration \\
\hline 38 & $\omega$ & $\sec ^{-1}$ & the angular velocity of the crank \\
\hline 39 & $\varphi$ & degree & the angle of crank rotation \\
\hline 40 & $\lambda$ & - & $\begin{array}{l}\text { the dimensionless kinematic constant which characterizes the relationship of the crank radius to the length of } \\
\text { the working part of the cable of the pumping unit }\end{array}$ \\
\hline 41 & $\varepsilon$ & - & the relative eccentricity \\
\hline 42 & $E$ & $\mathrm{~m}$ & the deaxial value \\
\hline 43 & $\Psi_{d}$ & - & the dynamic factor \\
\hline 44 & $C_{a}$ & - & the Cauchy parameter \\
\hline 45 & $H$ & $\mathrm{~m}$ & the length of the column rods (pump shutter depth) \\
\hline 46 & $v_{s}$ & $\mathrm{~m} / \mathrm{sec}$ & the sound velocity in the column rods \\
\hline 47 & $m$ & $\mathrm{~kg}$ & the mass acting at point $\mathrm{f}$ during the up- and downstrokes \\
\hline 48 & $k_{d}$ & - & the dynamic coefficient \\
\hline
\end{tabular}

\section{Literature}

Abdullaev A.H., Najafov A.M., Ahmedov B.B., 2016. New mechanical drive for sucker rod pumps for oil production: Scientific, technical and industrial journal, Bulletin of Mechanical Engineering, 9: 19-25.

Abdullaev A.H., Najafov A.M., Ahmedov B.B., Gasimov R.M., 2019. Beamless rocking machine of sucker rod pump units. The Eurasian Patent Organization (EAPO). https://www.eapo.org/ ru/patents/reestr/patent.php?id=32268

Adonin A.N., 1973. To the calculation of the loads acting on the bars of a deep pump. Azerbaijan Oil Industry, 4: 44-46.

Agamalov G.B., Aliev Z.Z., Romanova N.A., Rizvanov R.R., 2010. Method of calculating the weight of the wellhead balancing system of the pumping unit. Oil and gas business: 3-9.

Ahmedov B.B., 2016. Investigation of the method of balancing the new design of the pumping unit. Journal of Machinery, 5: 13-18.

Ahmedov B.B, Kerimov S.K., Jafarov E.A., 2015. The study of the kinematic parameters of a beamless rocking machine. Journal of Machine Science, 4(1): 29-32.

Ahmedov B.B., Najafov A.M., Abdullaev A.I., 2018. Determination of the kinematic parameters of the new constructive solution of the beamless sucker-rod pump. Journal of Structural Engineering \& Applied Mechanics, 1(3): 128-135.

Aliverdizade K.S., 1951. Balanced individual drives of a deep-well pumping unit (pumping units). Azneftizdat, Baku, 215.
Chicherov L.G., Molchanov G.V., Rabinovich A.M., 1987. Calculation and design of oilfield equipment. Nedra, Moscow, 422.

Ivanovsky V.N., Darishchev V.I., Kashtanov V.S., Sabirov A.A., Peking S.S., 2002. Well pumping installations for oil production. Oil and Gas, Moscow, 824.

Mishchenko I.T., 2003. Downhole oil production: Textbook for universities. Federal State Unitary Enterprise Publishing House, The Gubkin Russian State University of Oil and Gas, Moscow, 816.

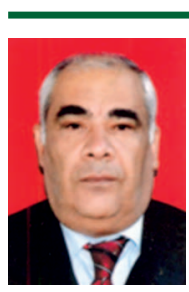

Beyali AHMEDOV, PhD

Assistant professor at Department of Machine Design of Azerbaijan Technical University

H. Javid ave 25, Baku, Azerbaijan, AZ 1073

E-mail:ahmedov.bevali@mail.ru

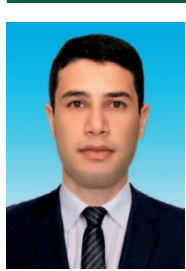

Anar HAJIYEV, MA

Senior lecturer at Department of Machine Design of Azerbaijan Technical University

Address: H. Javid ave 25, Baku, Azerbaijan, AZ 1073

E-mail: anar_hajiyev_1991@mail.ru 